\title{
Glioblastoma 長期生存例の免疫学的検討
}

\author{
㟯浦 一喜・森 照明 \\ 片倉 隆一・鈴木 二郎

\section{Immunological Study in Long-term Survivals of Glioblastoma}

\author{
Katsuyoshi Mineura, Teruaki Mori, Ryuichi Katakura and Jiro Suzuki \\ Division of Neurosurgery, Institute of Brain Diseases, Tohoku University
}

\begin{abstract}
Summary
Adequate follow-ups were obtained in 173 of 179 cases $(96.6 \%)$ of histologically verified glioblastoma patients experienced at Tohoku University Hospital during the 30 years from 1947 to 1977 Excluding 10 pre- and the 27 postoperative deaths within one month, the survival rates of the remaining 136 postoperative cascs after one, 3 and 5 years wcre $55 \%, 24 \%$ and $12 \%$ respectively.

Of the 14 cases who survived more than 5 years, 6 cascs $(4 / 6$ males, $12 \sim 52$ years old) are still alive and were the subject of this immunological study. The results of the study revealed that; 1) cytotoxicity of lymphocytes against KS-1 cells (established cell line derived from human glioblastoma) was augmented both preoperatively and within one month postoperatively in glioblastoma cases without radiation and chemotherapy. In long-term survivals of glioblastoma, cytotoxicity of lymphocytes was depressed significantly $(\mathbf{p}<0.01)$ to the level of healthy persons. In cytotoxicity-augumented glioblastoma cases, the administration of the anti-cancer drug made the cytotoxicity of lymphocytes depressed; 2) value of $\mathrm{T}$-cells and count of peripheral lymphocytes were not significantly different among the preoperative patients, postoperative cases and the long-term survivals of glioblastoma; other preoperative brain tumor cases; and healthy persons; 3) tuberculin reaction was negative in 2 and positive in 4 of 6 longterm survivals; and 4) titer of serum immunoglobulin in long-term survivals were within the normal range.

Judging from the above results, we concluded that immunity in long-term survivals is similar to healthy individuals.
\end{abstract}

\section{Key words : glioblastoma, long-term survivals, immunological study, cytotoxicity of lymphocytes}

\section{Iはじめに}

原発性悪性脑腫場である glioblastoma 注，これまでに 手術㧍よび種々の補助療法の試みがなされているにもか かわらず，以まだ満足すべき治療成績は得られていな い.すなわら, 大斗名術後 1 年以内に死亡して捛り，1 年生存率 $13 \sim 40 \%, 5$ 年生存率 $0 \sim 7 \%$ とい5現況であ

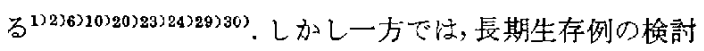
がなされ10年以上の生存例の報告も散見される

今回，我々はこれらの長期生存例の特徴を検索するた
め，現在まで汇当教室で経験した 5 年以上の長期生存 14 例中, 現在生存中の 6 例について免疫学的検討を加えた ので埌告する.

\section{II 対象および方法}

1977年 3 月までの過去30年問に当教宝で組織学的に再 検討しえた glioblastoma (astrocytoma grade III, IV) は 179症例である，そのちち術後1 力月以上生存した136例

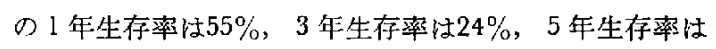
$12 \%$ でる.

東北大学脳研脑神経外科

[連絡先 : $\overline{\mathbf{T}} 982$ 仙台市長町5-13-1, 東北大学脳研媨神経外科, 峷浦一喜]

1978年 9 月 27 日 受稿 
Table 1 Clinical summary in long-term survivals of glioblastoma

\begin{tabular}{|c|c|c|c|c|c|c|c|c|c|c|}
\hline No. & Case & Sex & Age & $\begin{array}{l}\text { Initial } \\
\text { Symptom }\end{array}$ & Location & Operation & Radiation & Chemotherapy & Histology & $\begin{array}{l}\text { Survival } \\
\text { Pcriod }\end{array}$ \\
\hline 1 & C.K. & $\mathrm{F}$ & 5 & convulsion & $\mathrm{L} \mathrm{PO}$ & total & - & - & IV & $10 \mathrm{Y} 8 \mathrm{M}^{*}$ \\
\hline 2 & H.S. & $\mathrm{M}$ & 3 & hemiparesis & $\mathrm{R} F \mathrm{~T}$ & tolal & + & - & III & $9 \mathrm{Y} *$ \\
\hline 3 & Y.S. & M & 16 & headache & $\begin{array}{l}\text { L lateral } \\
\text { ventricle }\end{array}$ & total & + & - & $\mathrm{N}$ & $7 \mathbf{Y} 3 \mathbf{M}^{*}$ \\
\hline 4 & H.M. & M & 38 & headache & $\mathrm{R} \mathrm{O}$ & total & - & - & III & $6 \mathrm{Y} 1 \mathrm{M}^{*}$ \\
\hline 5 & T.M. & $\mathrm{F}$ & 15 & leadache & $\mathrm{R} T$ & total & $i$ & - & III & $5 \mathrm{Y} 5 \mathrm{M}^{*}$ \\
\hline 6 & S.K. & M & 47 & headache & Bifrontál & sublotal & $-(3)$ & $\frac{\mathrm{CQ}}{\mathrm{PT}-20 i}$ & IV & $5 \mathrm{Y} 3 \mathrm{M}^{*}$ \\
\hline 7 & T.K. & M & 26 & headache & L F & total & + & & III & $6 \mathrm{Y}$ \\
\hline 8 & Т.H. & $\mathrm{F}$ & 51 & convulsion & I. $\mathrm{O}$ & total & - & & III & $5 Y 11 \mathrm{M}$ \\
\hline 9 & S.S. & $\mathrm{F}$ & 13 & diplopia & I. $\mathrm{F}$ & subtotal & + & - - & IV & $5 \mathrm{Y} 9 \mathrm{M}$ \\
\hline 10 & Y.S. & $\mathbf{F}$ & 25 & headache & L F & $\operatorname{total}(2)$ & $-(2)$ & - & $\mathrm{III} \rightarrow \mathrm{IV}$ & $9 \mathrm{Y} 6 \mathrm{M}$ \\
\hline 11 & S.Y. & $\mathrm{F}$ & 41 & headache & L, $\mathrm{F}$ & $\begin{array}{l}\text { total }(1) \\
\text { subtolal(1) }\end{array}$ & $\perp$. & - & $\mathrm{II} \rightarrow \mathrm{IV}$ & $7 Y 10 \mathrm{M}$ \\
\hline 12 & T.K. & $\mathbf{M}$ & 32 & convulsion & $\mathbf{L} \mathbf{F} \mathrm{T}$ & $\operatorname{total}(2)$ & - & - & $\mathrm{I} \sim \mathrm{II} \rightarrow \mathrm{III}$ & $6 \mathrm{Y} 10 \mathrm{MI}$ \\
\hline 13 & J.M. & $M$ & 18 & convulsion & $\mathrm{R} F \mathrm{P}$ & total $(2)$ & + & - & $N \rightarrow I V$ & $6 \mathrm{Y} 2 \mathrm{M}$ \\
\hline 14 & S.F. & $M$ & 27 & convulsion & L F & subtotal (3) & $+(2)$ & $\begin{array}{c}\text { BLM } \\
\text { Vincristin }\end{array}$ & $\mathrm{II} \rightarrow \mathrm{III}$ & $5 \mathrm{Y} 9 \mathrm{M}$ \\
\hline
\end{tabular}

L: left R: right $F$ : frontal $T$ : temporal $P$ : parietal $O$ : occipital CQ: Carboquone BLM: Bleomycin ( ): times of operation, or radiation

*: alive on March 31 in 1977

5 年以上.正期生存例法14例であり (Table 1), この 5ち現在生存中の6 例 (case 1 6) : :

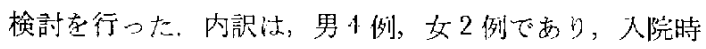

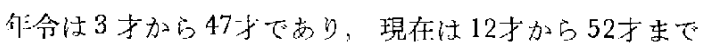

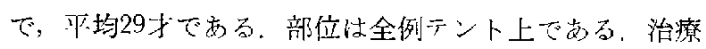

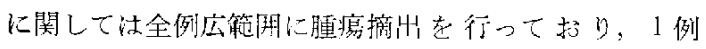

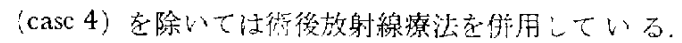
放射線潦法は，Tele- ${ }^{60} \mathrm{Co}$ 在用いクノール4, 550 6,560 $\mathrm{rad}$ 照射している。化学燎法は，再㥕の1例 (case 6) にのみ実施して扣り：台計 CQ $57 \mathrm{mg}$ 持続動注し， FT-20,716 g t経口にて投与し，同時に4,550 rad，さら に6,000 rad 02タールの ${ }^{60} \mathrm{Co}$ 照射名行执九。

現存全例ステロイド威执よざ抗嵒珴は服川しておら ず，最終治療加最短て 1 年 8 力月以上経過している (case 6).4例 (case 1，3，4，5） は有意0日常生活を 送って抢り，2例(case 2，6) は介助が必要な快態であ る. 生存期間沬術後 5 年 3 力月 10年 8 力月であり, 平 均 8 年 9 力月である。侁疫学的検菜の対照群として健常 人をとり，さらに glioblastoma り術们例打上び獄挼 1 一 2 力月で化学, 放射線療法施行肖ijの例 (glioblastoma 術

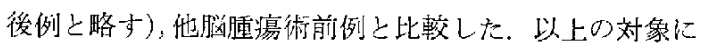
つき，下記の項目老検討した。

\section{1. リンパ球の cytotoxic activity}

高杉らの方法に準じ測定しだ28 ，摽的細胞として は, ヒト glioblastoma 由来の established ccll lineで苏 るKS-1 cellを用いだ!。リンパ球は被験者の末椎血上 り Ficoll-Isopaque法にて抽出した.リンハ球のcytotoxic activity は以下 cytotoxicity て声現した。

cytotoxicity $\%$

$$
=\left(1 \frac{\text { No. of surviving cells } / \text { well in MLTC }}{\text { No. of surviving cells well in control }}\right) \times 100
$$

MLTC: mixed lymphocyte-tumor cell culture

\section{T-cell}

羊赤血梂（SRBC）によるロゼット形成細胞を T-cell (Thymus-derived lymphocyte) として太田ら ${ }^{35)}$ の変法 にて测走した. Ficoll-Isopaque法にて分離した末梢血り ンパ球を cold $\mathrm{GVB}^{++}$(pll 7.2, $0.1 \%$ gelatin 含も) で 2 住洗ったあと，リンパ球が $1 \sim 2 \times 10^{6} / \mathrm{m} l$ となよ 5 に韭働化ウシ胎児血清 (FCS) を加えた，一方，SR一

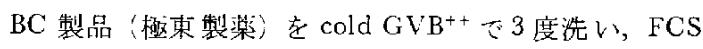
で $1 \%$ に稀秎しておき，これらのリンバ归，SRBCをそ れぞれ0.1 ml だつ mix した. それを $1,000 \mathrm{rpm} 5$ 分間 遠心し，ただちに再浮遊させてリンパ球を数え， 3 個以 上の $\mathrm{SRBC}$ を付着したものを $\mathrm{T}$-cell とした。 


\section{3. 末梢リンパ球数}

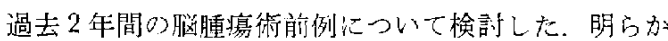
に感染等があり白血球增多症を認めたものは除外した。

\section{4. ツベルクリン反応}

精製ツベルクリン液一般診断用(日本 $\mathrm{BCG}$ 社製)

$0.1 \mathrm{~m} l$ 煎腕后侧皮内に注射し，48時間後に判定し，9 $\mathrm{mm}$ 以下を陰性，10 $\mathrm{mm}$ 以上を陽性とした。

\section{5. 免疫グロブリン}

HYLAND 社製 Immunoplate III 辛用い，单純放射状 免癋昖散法により血清 IgG，A，M を定量した。なお，

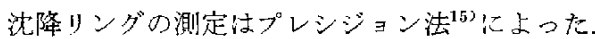

\section{II 結 果}

\section{1.リンパ球の cytotoxic activity}

Glioblastoma 街前 6 例では 59.8+13.7\%（平均值土 SD), glioblastoma 術後6 例では56.5土14.0\%でまった が，健常人 20 例では $4.3 \pm 14.7 \%$ ，長期生存 6 例では $15.3 \pm 19.9 \%$ で方った. Glioblastoma 術竍，術㣪例と 健常人および長期生存例との間に有意差が証められた $\langle\mathrm{p}<0.01$ )。良性脳腫瘍 (neurinoma 7 例, meningioma 1 例, craniopharyngioma 2 例) 術前 10 例で $42.1 \pm$ $25.1 \%$ あり，健常人との間にのみ有意差を認めた $(\mathrm{p}<0.01)$. (Fig. 1)

さらに glioblastomaの 2 症例に関して暗抗癌㓮投与の 前後において cytotoxicity 在追胁測定しえたか，抗癌剂 投与前の強い cytotoxicity は投与期間中には弱くなり，

投与終了後再び堌強していることが認められた(Fig. 2)。

\section{T-cell}

Glioblastoma 術前 6 例 $55.7 \pm 8.1 \%$, glioblastoma堆 後 6 例 $58.7 \pm 10.8 \%$ ，良性䏼䏦瘍（meningioma 3 例， neurinoma 2 例, ependymoma 1 例) 術前 6 例 $53.3 \pm 12.1$ $\%$ ，長期生存 6 例 $52.7 \pm 4.1 \%$ ，健常人 20 例 $58.5 \pm 6.6 \%$ であり，いずれの間にも統計学的有意差は認かられなか ote (Fig. 3).

\section{3. 末梢リンバ球数}

Glioblastoma 術前 17 例 $1,930 \pm 746 / \mathrm{mm}^{3}$, astrocytoma 6 例 $1,690 \pm 529 / \mathrm{mm}^{3}$, pituitary adenoma 20 例 $2,190 \pm 820 / \mathrm{mm}^{3}$, meningioma 12 例 $2,170 \pm 714 / \mathrm{mm}^{3}$, neurinoma 9 例 $1,750 \pm 789 / \mathrm{mm}^{3}$ ，長期生存 6 例 $2,010 \pm$ $849 / \mathrm{mm}^{3}$, 健常人 15 例 $2,220 \pm 701 / \mathrm{mm}^{3}$ 上全体的には上 の閒にも有意班は認められなかった。しかし先の5ち， リンパ球数 $1,500 / \mathrm{mm}^{3}$ 以下の症例について検討すると， 健常人では15例中 1 例 $(6.7 \%)$ であるのに比心゙，glioblastoma, astrocytoma, neurinoma では30\%以上古め て扮り，さらに長期生存例で舟 6 例中 2 例と末梢りンパ

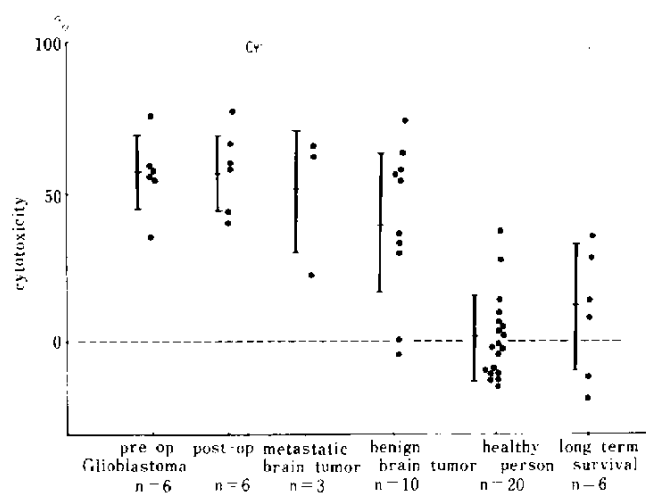

Fig. 1 Cytotoxicity of lymphocytes in patients with brain tumors.

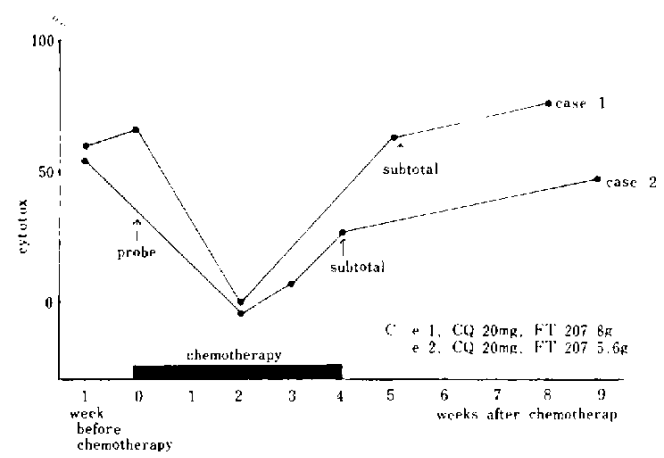

Fig. 2 Changes of cytotoxicity of lymphocytes during the chemotherapy in 2 patients with glioblastoma.

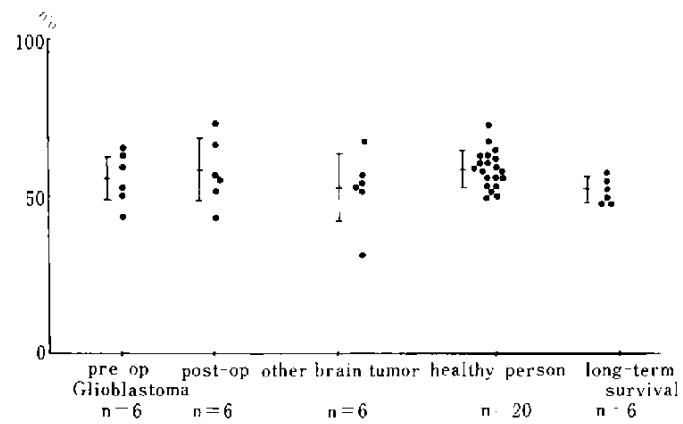

Fig. 3 T-cells value in patients with brain tumors.

球の减少傾向にある症例がみられた（Fig. 4)。

\section{4. ッベルクリン反応}

陰性率を比較すると，glioblastoma 術前 17 例 中 8 例 $(47 \%)$, neurinoma 9 例 中 4 例 $(44 \%)$, meningioma 12例中 5 例 $(42 \%)$, pituitary adenoma 17例中 5 例 $(29$ $\%)$ ，長期生存 6 例中 2 例 $(33 \%)$ であった。なお，健常 人は22例中 1 例 $(5 \%)$ であった。 


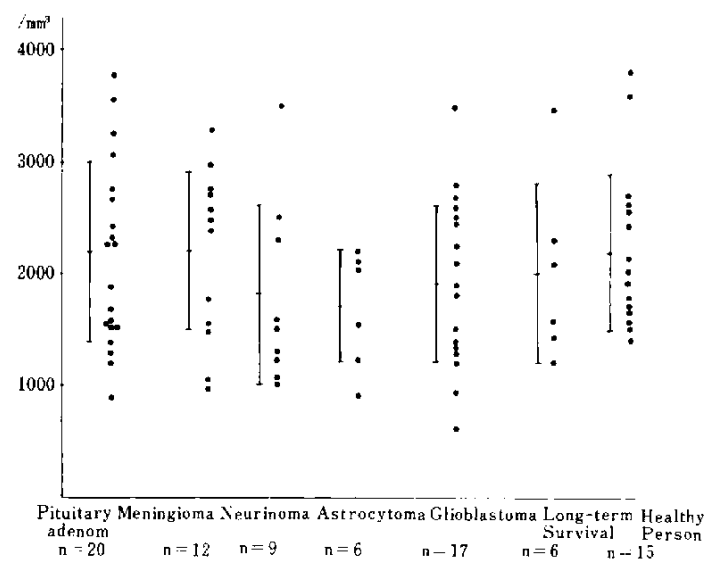

Fig. 4 Counts of peripheral lymphocytes in paticrits with brain turnors.

Table 2 Tuberculin reaction in paticnts with brin tumors

\begin{tabular}{|c|c|c|c|c|}
\hline & Case & Negative & Positive & $\mathrm{N} / \mathrm{N}+\mathrm{P}(\%)$ \\
\hline $\begin{array}{l}\text { Pituitary } \\
\text { adenoma }\end{array}$ & 17 & 5 & 12 & 29 \\
\hline Meningioma & 12 & 5 & 7 & 42 \\
\hline Neurinoma & 9 & 4 & 5 & 44 \\
\hline Astrocytoma & 5 & 2 & 3 & 40 \\
\hline Glioblastoma & 17 & 8 & 9 & 47 \\
\hline $\begin{array}{l}\text { Long-term } \\
\text { survival }\end{array}$ & 6 & 2 & 4 & 33 \\
\hline $\begin{array}{l}\text { Healthy } \\
\text { adult person }\end{array}$ & 22 & 1 & 21 & 5 \\
\hline
\end{tabular}

$(1975 \sim 1976)$

Glioblastoma は健常人に比ベ明らかに高い陰性率示 している $(\mathrm{p}<0.01) か ゙ ，$ 他の良性脳腫瘍との問に注差 注なく, 長期生存例との間にも大差は認められなかった

(Table 2).

\section{5. 免疫グロブリン}

長期生存 6 例中 1 例で $\mathrm{IgG} か 22,300 \mathrm{mg} / \mathrm{d} l$ と高值を示 したが，他の症例で社正常值を示して扔り，IgA，M は 全例正常值であった ${ }^{16)}$. 長期生存 6 例は，血清蛋白およ び分画, 肝機能検查に执いて異常值は認めなかった( Table 3).

\section{IN 考察}

近年, 脳腫珤患者の免疫状態を示す種々のパラメータ 一に関する報告と腫瘍特異抗原を示唆する報告32445)89122 13)14)18321222)253)26227)31332)38394) が多くみられるようになって きた. 我タもこれまでに術前および再発 glioblastoma患
Table 3 Serum immunoglobulin in long-term survivals of glioblastoma

\begin{tabular}{|c|c|c|c|c|c|c|}
\hline No. & Case & Sex & Age* & $\begin{array}{l}\operatorname{IgG} \\
(\mathrm{mg} / \mathrm{d} l)\end{array}$ & $\begin{array}{l}\operatorname{Ig} \Lambda \\
(\mathrm{mg} d \mathrm{~d} l)\end{array}$ & $\underset{(\mathrm{mg} / \mathrm{d} l)}{\operatorname{IgM}}$ \\
\hline 1 & C. K. & $\mathbf{F}$ & 20 & 2300 & 340 & 105 \\
\hline 2 & H.S. & $\mathrm{M}$ & 12 & 860 & 160 & 84 \\
\hline 3 & Y.S. & M & 24 & 820 & 360 & 130 \\
\hline 4 & H.M. & M & 44 & 1200 & 430 & 200 \\
\hline 5 & T.M. & $\mathbf{F}$ & 20 & 1200 & 170 & 160 \\
\hline 6 & S.K. & M & 52 & 1400 & 370 & 98 \\
\hline \multicolumn{4}{|c|}{ Normal 'Titer } & $887-1940$ & $121-593$ & $65-264$ \\
\hline
\end{tabular}

者の末梢!ンバ球注，健常人のそれと比べて glioblastoma cell に対し有意门差老持って強いcytoroxicity 走示 すことを明らなにしてきたがフ199，今回も同様の結果を 得，再確認した，諸家の脳腫湯患者リンパ球の cytotoxicity に関する報告でも，方法おらび targct cell 等に若干

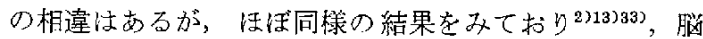
腫汮特異抗原の存在を示唆している。

Glioblastoma 患者リンパ球の cytotoxicity $の$ 変動に関 する報告注みられないが，我々の検索で注畽煌摘出後 1

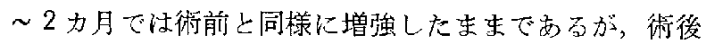
5 年以上の長期生存例では健常人と同程度にまで減弱し ていた。このことは手術および補助潦法により腫瘍すな わち抗原が消失減弱するにつれ，免疫監視機構の担い手 であるリンパ球の抗腫瘍効果も弱まり,リンパ球のcytotoxicity 方減弱したものと考えられた。

したがって再発寸れば，リンパ球は再び抗腫瘍効果を 持ち cytotoxicity は增強するものと考えられる。このよ 5にリンパ球の cytotoxicity が抗原量に呼応して変動す ると思われるので術後の免投学的パラメーターとして有 効と考えられるが，抗䍄剂の投与に上りリンパ球のcytotoxicity は容易に減弱するため，抗癌剂投与中の症例で 崔発の指標となりえないこともあり注意を要する。ま た Heppner らの報告的にもみられるように，cell-line 化された細胞を target cell として長期間 cytotoxicity follow していく場合, target cell の抗原性の変化による cytotoxicityの変動むみられることもあり，さらに注意が 必要である。

次に、リンバ球の subpopulation である T-cellに関し て注, glioblastoma 術前, 術後, 他脳腫富例, 長期生存 例，健常人との間に有意差は婄めず，祖父江らの報告 ${ }^{26)}$ と一致した. 今後はさらに, Helper-T, Killer-T, suppressor-T 等の subset に関しても検討していくことが必 
要と思われた。

末梢りンパ球数なよびッベルクリン反応に関しては， 従来, 脳腫瘍患者で末梢りンパ球数の減少; ッベルクリ ン反灾の陰性化など cell-mediated immunity の低下が 報告1726) されてきた。

今回，我々が検討した術前脳腫瘍患者では，末梢リン 分球数に関しては，glioblastoma 扔よび astrocytoma 患 者において平均值で多少低值を示した程度で健常人との 間に明らかな有意差は認めなかったが、ッベルクリン反 応にて, 慆腫堭患者, 特に glioblastoma患者は健常人に 比べ高い陰性率を示し従来の報告と一致した，長期生存 例に関しては、ッベルクリン反応に扔いて健常人との間 に若干の差を認的るも，末梢りンハ球数掞よび免度グロ ブリン值は健常人との間汇差は認められなかった。

以上のことより，我々が免疫学的パラメーターとして 検索しえた項目に扔いては，結局長期生存例俚健常人と の間に明らかな有意差は認めず, 免疫状態は健常人とほ ぼ同様で岁ると言える。このことは手術执よび補助療法 が効索泰して腫瘍が減少，消失すれば，腫瘍という抗原 に呼応した免疫状態の変化注正常化していくと思われ た.この状態は抗原認識扣よび抗体産生力の不顕化であ るのか，志るい悄失であるのか，またさらにどの時点 でそれが行われるのか，今後長期間にわたる検討が必要 と考えられた。

\section{$\mathrm{V}$ 結 論}

術後 5 年以上生存している glioblastoma患者 6 例につ いて, 免疫学的検索として, リンパ球の cytotoxicity, T-cell, 末梢リンパ球数, ツベルクリン反応, 免疫グロ ブリンについて検討した。

1. リンパ球の cytotoxicity は glioblastoma 術前例, 街後例において堌強し, 長期生存例では健常人と同程度 まて低下していた。

2. T-cell, 末梢リンパ球数は, glioblastoma 術前 例, 他脑腫瘍例, 長期生存例, 健常人との閒に有意差は 認められなかった。

3. ツベルクリン反応は，長期生存例 6 例中 2 例が陰 性であった.

4. 長期生存例に㧧いて，血清免疫グロブリンは正常 範围であった。

以上より，長期生存例の免疫状態法健常人とほぼ同じ であると結論した。

な扮本稿の要旨は, 昭和52年10月27日第36回日本媨神 経外科学会総会（於・大阪）に扔いて発表した。
文献

1) Bloom, H. J. G., Peckhan, M. J., Richardson, A. E., Alexander, P. A. \& Payne, P. M.: A controlled trial to assess the value of specific active immunotherapy in patients treated by radical surgery and radiotherapy. $\mathrm{Br} J$ Cancer 27: 253-267, 1973

2) Bovchard, J. \& Pierce, C. B.: Radiation therapy in management of neoplasms of central nervous system, with special note in regard to children: Twenty years' experience, 1939-1958. Am J Roentgenol 84: 610-628, 1960

3) Brooks, W. H., Caldwell, H. D. \& MortaRA, R. H.: Immune responses in patients with glioma. Surg Neurol 2: 419-423, 1974

4) Eggers, A. E.: Autoradiographic and fluorescence antibody studies of the human host immune response to gliomas. Neurolog $y 22: 246-250$, 1972

5) Febvre, H., Maunoury, R., Constans, J. P. \& Troulllas, P.: Réactions D'hypersensibilité Retardée Avec des Lingnécs de Cellules Tumorales Cultivées in Vitro Chez des Malades Porteurs de Tumeurs Cérébrales Malignes.Int $J$ Cancer 10; 221-232, 1972

6) Frankel, S. A. \& German, W. J.: Glioblastoma multiforme. Review of 219 cascs with regard to natural history, pathology, diagnostic methods, and treatment. I Neurosurg 15: 489 503,1958

7) 府川 修, 森 照明, 㻕 重昭, 荒井澄夫： Cytotoxic activity $と$ transfer factor によるその 増強效果について. Neurol Med Chir 17 (Part II): 115-122, 1977

8) Hellström, K. E. \& Hellström, I.: Cellular immunity against tumor antigens. Adv Cancer Res 12: 167-223, 1969

9) Heppener, G., Henry, E., Stolbach, L., Cummings, F., McDonough, E. \& Calabresi, P.: Problems in the clinical use of the microcytotoxicity assay for measuring cell-mediated immunity to tumor cells. Cancer Res 35: 19311937,1975

10) Jelsma, R. \& Bucy, P. C.: The treatment of glioblastoma maltiforme of the brain. $J$ Neurosurg 27: $388-400,1967$

11）神野哲夫，中沢恒幸，工藤達之：七卜悪性神 経腃芽腫. 長期継代培羡株 $の$ 細胞学的検索. 神 経進歩15：154-163，1971

12) Kumar, S. \& Taylor, G.: Specific lymphocytotoxicity and blocking factors in tumours of the central nervous system. Br J Cancer 28 (Supple I) : 135-141, 1973

13) Levy, N. L., Mahaley, M. S. \& Day, E. D.: 
In vitro demonstration of cell-mediated immunity to human brain tumors. Cancer Res 32 : $477-482,1972$

14) Mahaley, M. S. JR., Brooks, W. H., Roszman, T. L., Binger, D. D., Dudka, L. \& Richardson, S.: Immunobiology of primary intracranial tumors. Part 1: Studies of the cellular and humoral general immune competence of brain-tumor patients. $J$ Neurosurg 46 : $467-476,1977$

15) Mancini, G., Carbonard, A. O. \& Heremans, J. F.: Immunochemical quantitation of antigens by single radial immunodiffusion. Immunochemistry 2:235-254, 1965

16）松友隆志，吉团俊一，丁藤泰子，里中陽子： イムノプレートIII による免疼グロブリン正常值 の検討。臨床検查20：78-81，1976

17) 三木答金，佐野主司，高会公朋，水谷弘： 恶性脸腫缼忠者の BCGによ方補助免疫療法. 神 経外科16 (Part II) : 357-364, 1976

18) Mitts, M. G. \& Walker, A. E.: Autoimmune response to malignant glial tumours. Preliminary observation. Neurology 15:474 476, 1965

19) Mori, T., Fukawa, O., Aoki, A. \& Suzuki, J.: Cytotoxicity of lymphocytes in paticnts with brain tumors. Neurol Med Chir 13: 115, 1973

20) Netsky, M. G., August, B. \& Fowler, W.: The longevity of patients with glioblastoma multiforme. $J$ Neurosurg 7: 261-269, 1950

21) 織田祥史, 武内重二, 北田肇 : 脳腫易の特 異抗原。脳外 $1 ： 27-35,1973$

22) 小野豪一, 李 文相, 寺門敬夫，住江寛俊， 石井昌三：脳腫瘍の免癋学的診断㧍よび治療の 可能性. 神経外科16:419-426, 1976

23) Roth, J. C. \& Elvidge, A. R.: Glioblastoma multiforme: $\Lambda$ clinical survey, $J$ Neurosurg 17: $736-750,1960$
24）位野士司，佐藤 修：脳腫瘍，外科治燎 30 : $23-28,1974$

25）清水 隆，鬼頭健一， 以崎直美，久保長生， 喜多村孝一：这腫瘍患者の免疫能. 神経外科 16 : 337-347, 1976

26) 祖父江公紀，谷村憲一，寺林 征，石川尚之， 植木幸明：㨫腫瘍の免疫学的斫究（第 1 報）、媨 神経27：629-635，1975

27) 高倉公朋, SATYANEGARA, 任野た司, 小林富二

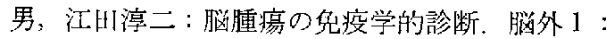
219-224, 1973

28) Takasugi, M. \& Klein, E.: A microassay for cell-mediated immunity. Transplantation 9: 219227,1970

29) 竹内一夫 : Glioblastoma の长期生存例と化学 漈法. 腷外 3：815-820，1975

30) Taveras, J. M., Thompson, H. G. \& Pool, J. L.: Should we treat glioblastoma multiforme? A Study of survival in 425 cases. $A m J$ Roentgenol $87: 473-479,1962$

31）寺林 征, 閏川和代, 谷村憲一, 植木幸明： 脳腫瘍患者の Blastogenesis. 腷外1：37-42，1973

32) Thomas, D. G., Lannigam, C. B. \& Behan, P. 9.: Impaired ccll-mediated immunity in human brain tumours. Lancet 1: 1389-1390, 1975

33) 植村正二郎，和田伸一，坚玉万典，松何康彦：

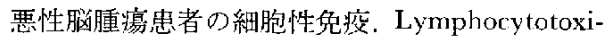
city と血清打上び骵没内 blocking factor $\sigma$ 術後 低下と回復. Neurol Med Chir 16 (Supple) : 67-68, 1976

34) Wailström, T., Linder, E., Saksela, E. \& Westermark, B.: Tumor-specific menbrane antigens in established ccll lines from gliomas. Cancer $34: 274-279,1974$

35) 矢田純一, 橘 武彦：ヒトリンパ球の Subpopulation D分别。兔疫奏験操作法 I, 日本免疫 学会編 : 473-475, 1972 